\title{
14. STABLE ISOTOPES OF OXYGEN AND CARBON IN CARBONATES FROM SITES 398 AND 116 OF THE DEEP SEA DRILLING PROJECT
}

\author{
Michael A. Arthur, A-031, Scripps Institution of Oceanography, La Jolla, California \\ Peter A. Scholle, U.S. Geological Survey, Oil and Gas Branch, Denver, Colorado \\ and \\ Phyllis Hasson, Princeton University, Department of Geological and Geophysical Sciences, \\ Princeton, New Jersey
}

\section{INTRODUCTION}

During the Deep Sea Drilling Project, pelagic carbonate sediments and calcareous planktonic and benthic organisms of Cretaceous and Cenozoic age were recovered from the Pacific Ocean (Douglas and Savin, 1971, 1973, 1975; Coplen and Schlanger, 1973; Schackleton and Kennett, 1975; Margolis et al., 1975; Matter et al., 1975). The construction of a preliminary oceanic paleotemperature scale based on these calcareous foraminifers and nannofossils has permitted the examination of diagenetic trends in oxygen isotopic composition as related to increasing burial and lithification of pelagic carbonates. Until recently, very little information of this type was available for the North Atlantic Ocean Basin.

DSDP Site 398 was drilled on the Iberian continental margin on the southern end of Galicia Bank (Figure 1) and penetrated over 1740 meters of sediment with good recovery. For the present study, samples were collected onboard ship for isotopic analysis with the hope that a continuous section from Maestrichtian through Paleogene time would enable documentation of paleotemperature trends across the Cretaceous-Tertiary boundary upwards to the Eocene-Oligocene interval, using planktonic and benthic foraminifers. Changes in the carbon isotopic composition $\left(\delta^{13} \mathrm{C}\right)$ of bulk samples of pelagic or hemipelagic carbonate sediments through time from the Early Cretaceous and Late Cretaceous-Paleogene interval were also examined in this study. The carbon isotope composition of bulk samples may give an indication of variations in factors controlling the oceanic carbon cycle, such as the burial rate of organic matter in marine sediment or oceanic productivity and circulation. Analysis of the oxygen isotopic composition $\left(\delta^{18} \mathrm{O}\right)$ of the same whole-rock samples was undertaken to investigate depositional and diagenetic trends related to age and depth of burial. In addition, bulk samples of foraminiferal nannofossil ooze and chalk of late Eocene through Pleistocene age were obtained from cores of Site 116, Leg 12 (Figure 1), from the eastern Hatton-Rockall Basin. These samples also illustrate gross paleotemperature trends and increasing diagenetic overprints related to depth of burial in the Hatton-Rockall Basin during the late Cenozoic.
Sediment of equivalent age at Hole 398D was incompletely cored however, Létolle (this volume) was provided whole-rock stable-isotope analyses of samples over some of this interval, and Grazzini (this volume has analyzed the isotope composition of additional planktic and benthic foraminifers.

\section{METHODS}

Samples were selected from the more calcareous portions of the interval from Maestrichtian through Eocene time (Figure 2); disaggregated using 10 per cent $\mathrm{H}_{2} \mathrm{O}_{2}$ in water, calgon, and mild heat; sieved to remove $<63 \mu \mathrm{m}$ material; and dried. Several species of calcareous planktonic and benthic foraminifers were picked from the material remaining from each sample. Species were selected on the basis of preservation (lack of test infilling by cement, test surface unencrusted, no recrystallization, and little or no signs of dissolution) and abundance. When possible, both globigerinid and globorotalid (or globotruncanid in Cretaceous samples) species from the same interval were analyzed for carbon and oxygen isotopic composition. Usually one or more benthic species (sometimes a whole assemblage) were also analyzed. Samples were analyzed at the Benedum Stable Isotope Lab, Brown University, by Robert Fifer under the direction of R. K. Matthews.

At Brown University, samples of nominal $0.3-\mathrm{mg}$ size were vacuum roasted at $380^{\circ} \mathrm{C}$ to remove volatile organics and reacted with orthophosphoric acid at $50^{\circ} \mathrm{C}$ to convert the carbonate to $\mathrm{CO}_{2}$. The $\mathrm{CO}_{2}$ was purified by two cold-trapping steps utilizing isopropyl alcohol and liquid nitrogen to trap water, and liquid nitrogen to move the $\mathrm{CO}_{2}$ down the line. The purified $\mathrm{CO}_{2}$ was then compared to the laboratory working standard gas in an on-line VG Micromass ${ }^{1} 602 \mathrm{C}$. Each string of data was bracketed with a $\mathrm{CaCO}_{3}$ lab standards and approximately $10 \%$ of all data points were duplicated. Precision of standards within the period of work was $\pm 0.1 \%$ of oxygen and $\pm 0.04 \%$ o for carbon. Precision of duplicates was $\pm 0.7 \%$ o for oxygen and $\pm 0.05 \%$ for carbon. Calibration to PDB was by

1 Use of trade names in this report is for descriptive purposes only, and does not constitute endorsement by the U.S. Geological Survey. 


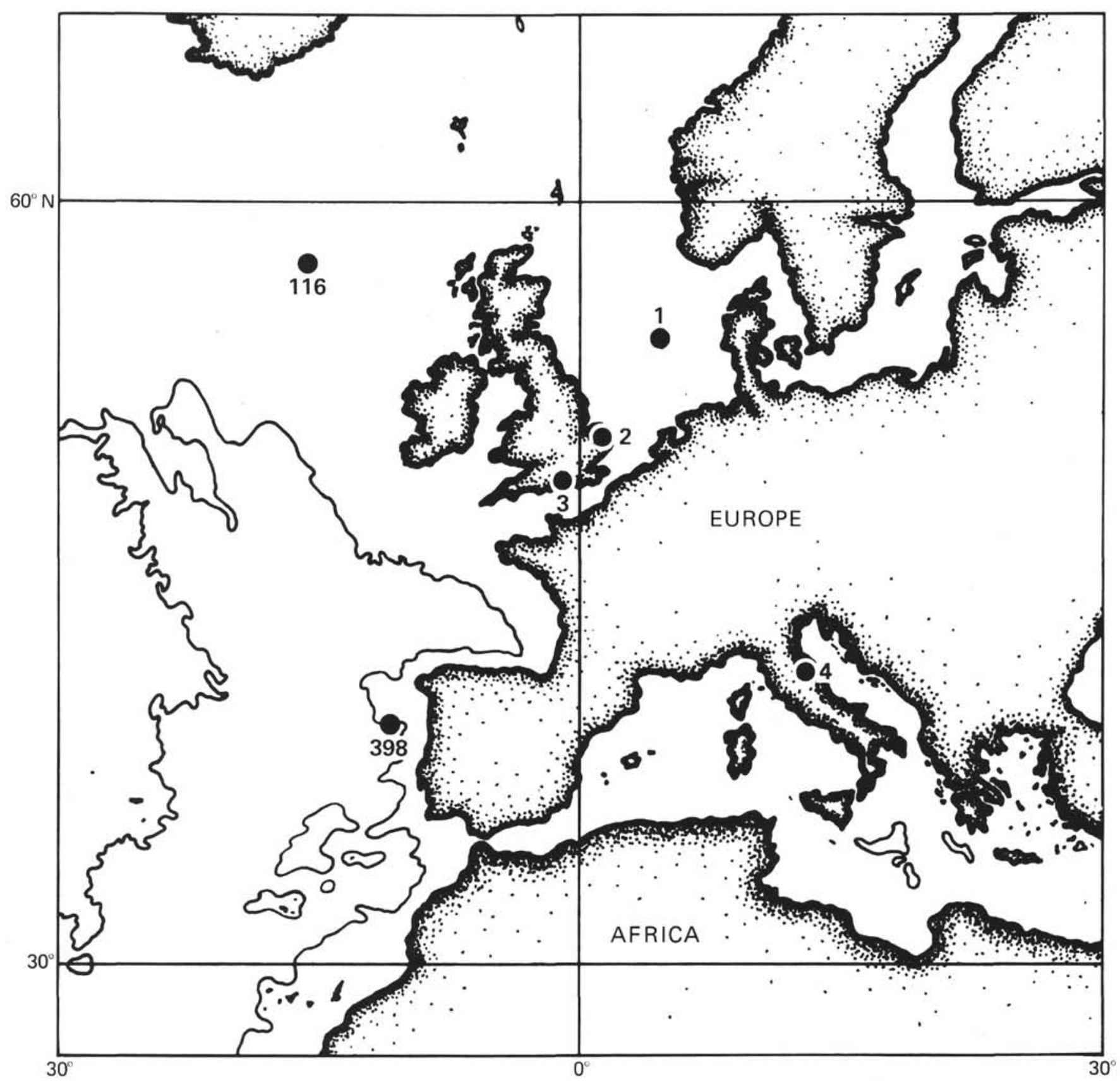

Figure 1. Index map of the North Atlantic showing DSDP Sites 116 and 398 and European pelagic chalk localities which yielded results used for construction of $\delta^{13} C$ curve (in Figure 4): (1) North Sea; (2) Norfolk, England; (3) Isle of Wight, England; (4) Gubbio, Italy.

way of "B-1" (Emiliani), "Fletton Clay Belemnite" (Shackleton), and McMaster University Standard 3. Agreement among the four labs is $\pm 0.2 \%$ for both oxygen and carbon.

Carbonate sediment from bulk samples of various lithologic types from Early Cretaceous to Oligocene age from Site 398 ( Leg 47B) was analyzed for oxygen and carbon isotopic composition at the Hawaii Institute of Geophysics, Stable Isotope Lab under the direction of P. Kroopnick and S. Margolis.

Bulk sediment samples were washed once with 30 per cent $\mathrm{H}_{2} \mathrm{O}_{2}$, then rinsed several times with distilled water. The sediment was then dried, ground to $<100$ $\mu \mathrm{m}$, and approximately $100 \mathrm{mg}$ was placed in a Wittenberg tube. The carbonate then was converted to $\mathrm{CO}_{2}$ gas by reaction with 100 per cent $\mathrm{H}_{3} \mathrm{PO}_{4}$ at $25^{\circ} \mathrm{C}$. The gas was analyzed with a Nuclide $3-60$ or $6-60$ RMS mass spectrometer and the results expressed as the per mil deviation from the PDB or SMOW isotopic standards (Goodney and Kroopnick, in press; Craig, 1957). The analytical reproducibility on homogeneous samples is \pm 0.10 per mil.

Samples of carbonate sediment of Eocene through Pliocene age from Site 116 (Leg 12), as well as mate- 


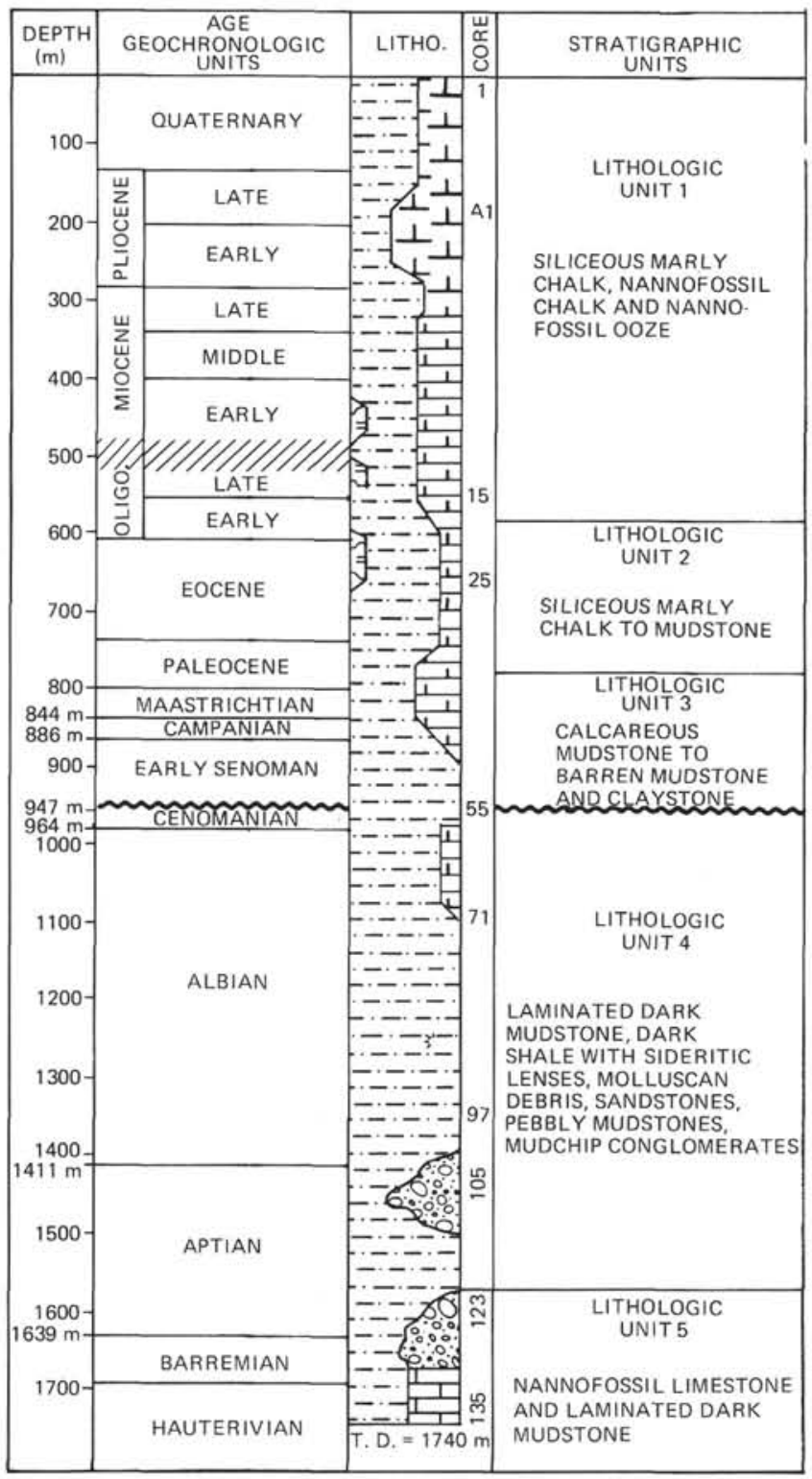

Figure 2. Age, lithology, and stratigraphic units for Site 398. Note generalized carbonate curve in lithology column.

rial from onshore sections in England and Italy, were analyzed for oxygen and carbon isotopic composition by Teledyne Isotopes, Inc.

\section{Bulk Samples}

\section{RESULTS}

The isotope compositions and general lithologic-petrographic features of all bulk samples are listed in Table 1. The samples from Site 398 are from 550 to 1740 meters in sub-bottom depth and from early Oligocene to Early Cretaceous (Hauterivian) in age. Samples from Site 116 (Leg 12) were recovered from sub-bottom depths between 0 and 854 meters and range from Pliocene through late Eocene in age. Both oxygen and carbon isotope compositions (notation in \% relative to PDB standard) are plotted by age in Figure 3 (Ceno- zoic and late Maestrichtian values) and Figure 4 (Cretaceous values). Létolle (this volume) has also analyzed bulk samples from some intervals of Site 398, and his values are plotted in these figures for comparison. The $\delta^{18} \mathrm{O}$ values of all bulk carbonate material of Cenozoic age from Sites 398 and 116 fall between +1 and $-1.5 \%$, a normal range for calcium carbonate in equilibrium with surface seawater in the range of $10^{\circ}$ to $25^{\circ} \mathrm{C}$ (Craig, 1965). In the upper part of Site 116 , values approach $+2 \%$, which may indicate much cooler surface temperatures from late Miocene to late Pliocene time. An overall trend toward downwardly decreasing (more negative) $\delta^{18} \mathrm{O}$ values in the bulk samples of Site 116 could be caused by progressive lithification of these pelagic carbonates from ooze to soft-chalk to harder chalk at the bottom of the hole. Such an evolution has been discussed for pelagic carbonates from the Pacific Ocean by Schlanger et al. (1973) Schlanger and Douglas (1974) and Matter et al. (1975), and for European chalks, especially from the North Sea, by Scholle $(1974,1977)$. However, the most negative values from Site 116 are $-1.3 \%$, which simply may indicate a higher surface temperature during late Eocene time that was followed by progressive cooling through the later Cenozoic. In fact, the overall trend and fluctuations in the Site 116 cores fairly accurately reflect the paleotemperature curve derived from Pacific isotope data for this part of Cenozoic time; i.e., warmer temperatures during the late Eocene, rapidly decreasing (more positive $\delta^{18} \mathrm{O}$ ) in early Oligocene time, a warming during the late Oligocene, reaching a peak during the early to middle Miocene, and cooling in the Pleistocene (Savin et al., 1975; Shackleton and Kennett, 1975). The trend and fluctuations in the Site 116 cores also correspond to patterns, inferred from calcareous plankton in the North Atlantic Ocean (Hag et al., 1977). These changes are relative, of course. Exact temperature differences cannot be calculated because of the varying proportions of calcareous nannofossils, and planktonic and benthic foraminifer in the bulk samples, and because of superimposed diagenetic effects such as the more negative $\delta^{18} \mathrm{O}$ values that result from progressive cementation as the depth of burial and burial temperature both increase (Scholle, 1974, 1977; Matter et al., 1975). One chalk sample of early Oligocene age from Site 116 gives an anomalous $\delta^{18} \mathrm{O}$ value of $+4.3 \%$. The isotopic composition of this sample is similar to that of the Braarudosphaera-rich chalks of early Oligocene age from the South Atlantic, analyzed and discussed by Lloyd and Hsü (1972).

Oxygen isotope analyses of bulk samples from Site 398 show no consistent trends toward decreasing $\delta^{18} \mathrm{O}$ values with depth in the hole, although the Early Cretaceous values vary between -1 and $-3 \%$ while Cenozoic values are generally more positive than $-1.5 \%$. The deepest samples, consisting of recrystallized nannofossil limestones of Hauterivian age, have average $\delta^{18} \mathrm{O}$ values of $-1.5 \%$, which are actually no more negative than some of the values from Cenozoic chalks at Sites 398 or 116 ; on the average Cenozoic $\delta^{18} \mathrm{O}$ values are about -0.5 at Site 398. Possible explanations 
TABLE 1

Bulk Sample Stable-Isotope Analyses

\begin{tabular}{|c|c|c|c|c|c|c|}
\hline $\begin{array}{l}\text { Sub-Bottom } \\
\text { Depth } \\
\text { (m) }\end{array}$ & $\begin{array}{c}\text { Sample } \\
\text { (Interval in } \mathrm{cm} \text { ) }\end{array}$ & Approximate Age & $\begin{array}{l}\text { Sample Description }{ }^{\mathrm{a}} \\
\text { and Remarks } \\
\text { (color on dry surface) }\end{array}$ & $\begin{array}{l}\text { Isotopic } \\
\delta 180 \\
\text { (per mil) }\end{array}$ & $\begin{array}{l}\text { Results } \\
\delta^{13} \mathrm{C} \\
\text { (per mil) }\end{array}$ & Comments \\
\hline \multicolumn{7}{|c|}{ Leg 47B, Hole 398D } \\
\hline 585 & $19-1,42-44$ & Early middle Oligocene & Lt. tan, chalky, burrow-mottled. & +0.39 & +1.70 & not plotted \\
\hline 603 & $20-6,107-109$ & Late middle Eocene(?) & $\begin{array}{l}\text { Lt. tan to dk. brown, nanno } \\
\text { marl; mottled. }\end{array}$ & -- & +0.79 & \\
\hline 605 & $21-2,39-41$ & Late middle Eocene(?) & $\begin{array}{l}\text { Grnish-gray; mottled with olive; } \\
\text { marly nanno chalk. }\end{array}$ & -0.38 & +2.01 & \\
\hline 619 & $22-4,112-114$ & Late middle Eocene(?) & $\begin{array}{l}\text { Beige mottled with olive, } \\
\text { slightly laminated siliceous } \\
\text { nanno marl. }\end{array}$ & -- & +1.56 & not plotted \\
\hline 625 & $23-2,61-63$ & Late middle Eocene & $\begin{array}{l}\text { Lt. grnish-beige with faint } \\
\text { mottles, siliceous nanno marl. }\end{array}$ & +0.29 & +1.26 & \\
\hline 632 & $24-1,26-28$ & Mid middle Eocene & $\begin{array}{l}\text { Grnish-gray, mottled, siliceous } \\
\text { nanno chalk. }\end{array}$ & +0.29 & +1.72 & \\
\hline 655 & $26-3,50-52$ & Mid middle Eocene & $\begin{array}{l}\text { Grn.-olive (still damp), faint } \\
\text { mottles, nanno marl. }\end{array}$ & -0.05 & +1.81 & \\
\hline 658 & $26-5,101-103$ & Mid middle Eocene & $\begin{array}{l}\text { Grnish-gray with flattened red } \\
\text { mottles, nanno marl. }\end{array}$ & -0.92 & +1.02 & \\
\hline 663 & $27-2,108-110$ & Mid middle Eocene & $\begin{array}{l}\text { Orange-tan mottles in dker. } \\
\text { brown; highly burrowed, nanno } \\
\text { marl. }\end{array}$ & -0.06 & +1.85 & \\
\hline 670 & $28-1,20-22$ & Mid middle Eocene & $\begin{array}{l}\text { Med. grnish. gray, relat. homog. } \\
\text { (red at base), nanno marl. }\end{array}$ & +0.09 & +2.46 & \\
\hline 682 & $29-2,98-100$ & Mid middle Eocene & $\begin{array}{l}\text { Reddish-tan, very faint mottles, } \\
\text { marl. }\end{array}$ & -0.07 & +2.24 & \\
\hline 699 & $31-1,78-80$ & Mid middle Eocene & $\begin{array}{l}\text { Olive-grn. with white lamin. } \\
\text { (chalky) and burrow fillings, } \\
\text { marly nanno chalk. }\end{array}$ & -2.10 & +0.64 & \\
\hline 708 & $32-1,17-19$ & Early middle Eocene & $\begin{array}{l}\text { Homogeneous lt. grn. (with } \\
\text { some red contamin. on outside) } \\
\text { marly nanno chalk. }\end{array}$ & +2.25 & -0.43 & no rerun \\
\hline 722 & $33-3,102-104$ & Early Eocene & $\begin{array}{l}\text { Lt. ol. grn. with lt. beige } \\
\text { mottles (highly bioturb.) nanno } \\
\text { chalk. }\end{array}$ & $\begin{array}{l}\mathrm{A}+0.08 \\
\mathrm{~B}+1.17\end{array}$ & $\begin{array}{l}+0.33 \\
+0.39\end{array}$ & $\begin{array}{l}\text { only A } \\
\text { plotted }\end{array}$ \\
\hline 727 & $34-1,11-13$ & Early Eocene & $\begin{array}{l}\text { Lt. beige-white, homogeneous } \\
\text { chalk. }\end{array}$ & +0.52 & +1.07 & \\
\hline 730 & $34-3,38-40$ & Early Eocene & $\begin{array}{l}\text { Lt. beige-tan, mottled marly } \\
\text { nanno chalk. }\end{array}$ & +0.09 & +1.56 & \\
\hline 737 & $35-1,65-67$ & Early Eocene & Lt. Beige, nanno chalk. & -0.55 & +0.92 & \\
\hline 748 & $36-2,83-85$ & Late Paleocene & $\begin{array}{l}\text { Tan to or. brown, mottled (lt.) } \\
\text { marl. }\end{array}$ & -0.65 & +2.75 & \\
\hline 756 & $37-1,89-91$ & Late Paleocene & $\begin{array}{l}\text { Med. or. tan.; faintly mottled } \\
\text { marl. }\end{array}$ & -0.35 & +2.91 & \\
\hline 761 & $37-5,10-12$ & Late Paleocene & $\begin{array}{l}\text { Med. ol.-gray with lt. beige } \\
\text { mottles, marl. }\end{array}$ & -0.71 & +3.13 & \\
\hline 767 & $38-2,65-67$ & Late Paleocene & Dker red-brown, mottled marl. & -2.18 & +1.52 & \\
\hline 776 & $39-2,41-43$ & Late Paleocene & $\begin{array}{l}\text { Bright red-orange and lter. } \\
\text { orange tan; highly mottled } \\
\text { marl. }\end{array}$ & -0.39 & +1.84 & \\
\hline 788 & $40-3,88-90$ & Early Paleocene & $\begin{array}{l}\text { Lt. grn.-gray; faintly mottled } \\
\text { nanno chalk. }\end{array}$ & -0.42 & +1.87 & \\
\hline 791 & $40-5,132-134$ & Early Paleocene & $\begin{array}{l}\text { Dk. red-brown; mottled (moldy } \\
\text { on surface, low } \mathrm{CaCO}_{3} \text { ); marl. }\end{array}$ & -0.50 & -0.75 & no rerun \\
\hline 795 & $41-2,37-39$ & Early Paleocene & Dk. red-brown; mottled marl. & -0.12 & +0.52 & \\
\hline 799 & $41-4,58-60$ & Latest Maestrichtian & $\begin{array}{l}\text { Lt. orange-tan with occasional } \\
\text { faint grn. mottles; marly chalk. }\end{array}$ & -0.39 & +2.43 & \\
\hline 803 & $41-7,16-19$ & Late Maestrichtian & $\begin{array}{l}\text { Dker. or. brown, homogeneous } \\
\text { marl. }\end{array}$ & -- & +2.17 & no rerun \\
\hline 806 & $42-3,8-10$ & Late Maestrichtian & $\begin{array}{l}\text { Dker orange brown with } \\
\text { occasional faint grn. mottles, } \\
\text { marl. }\end{array}$ & -0.19 & +2.43 & \\
\hline 813 & $43-1,62-64$ & Late Maestrichtian & $\begin{array}{l}\text { Orange-tan with lter. mottles, } \\
\text { marl. }\end{array}$ & -0.18 & +2.58 & \\
\hline 817 & $43-4,47-49$ & Late Maestrichtian & $\begin{array}{l}\text { Dk. red-brown, faint mottling, } \\
\text { marl. }\end{array}$ & -0.19 & +2.34 & \\
\hline 825 & $44-2,148-150$ & Late Maestrichtian & Lt. grn.-gray (soft), marly chalk. & -0.33 & +2.52 & \\
\hline
\end{tabular}


TABLE 1 - Continued

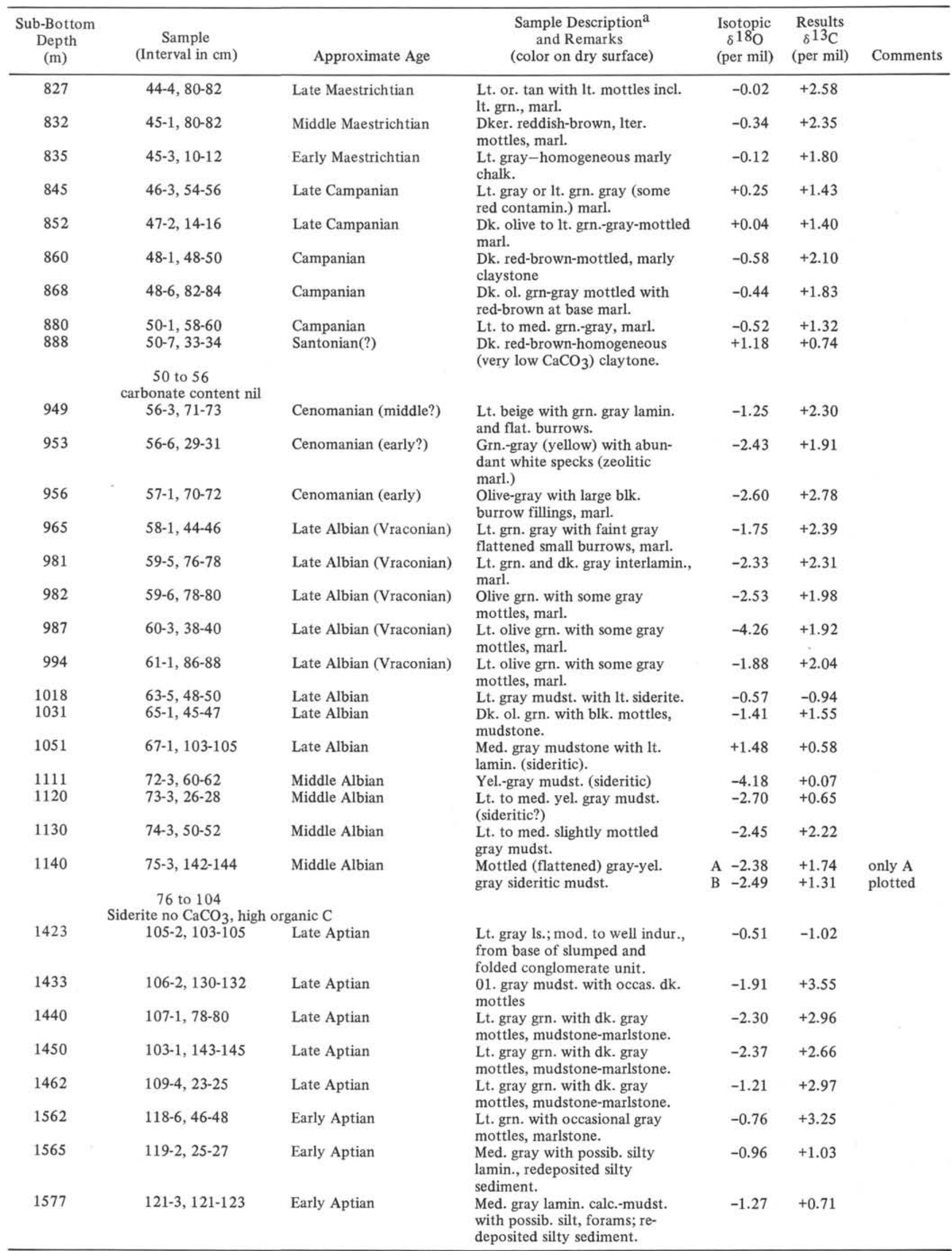


TABLE 1 - Continued

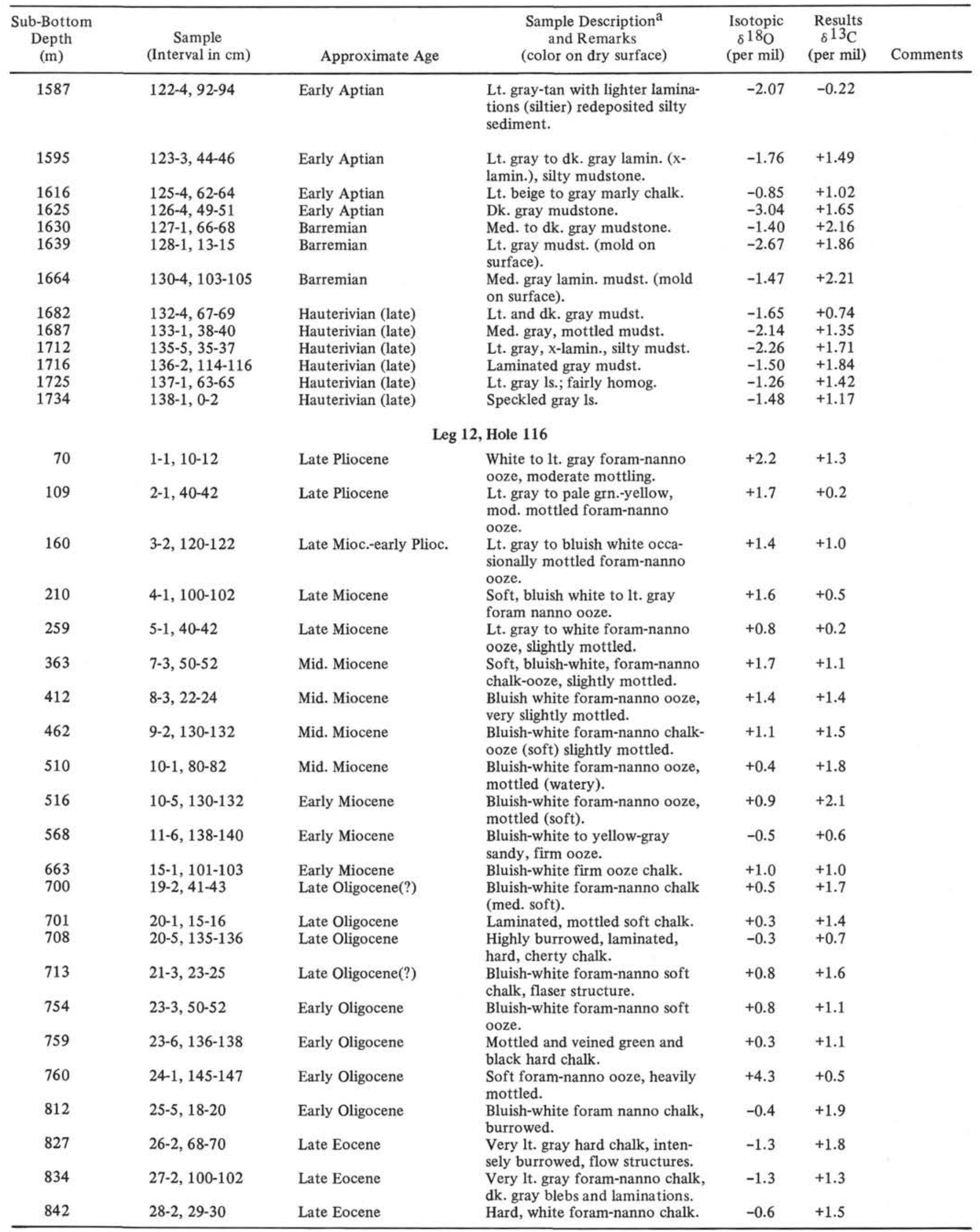

${ }^{\mathrm{a}}$ As opposed to initial shipboard description. 


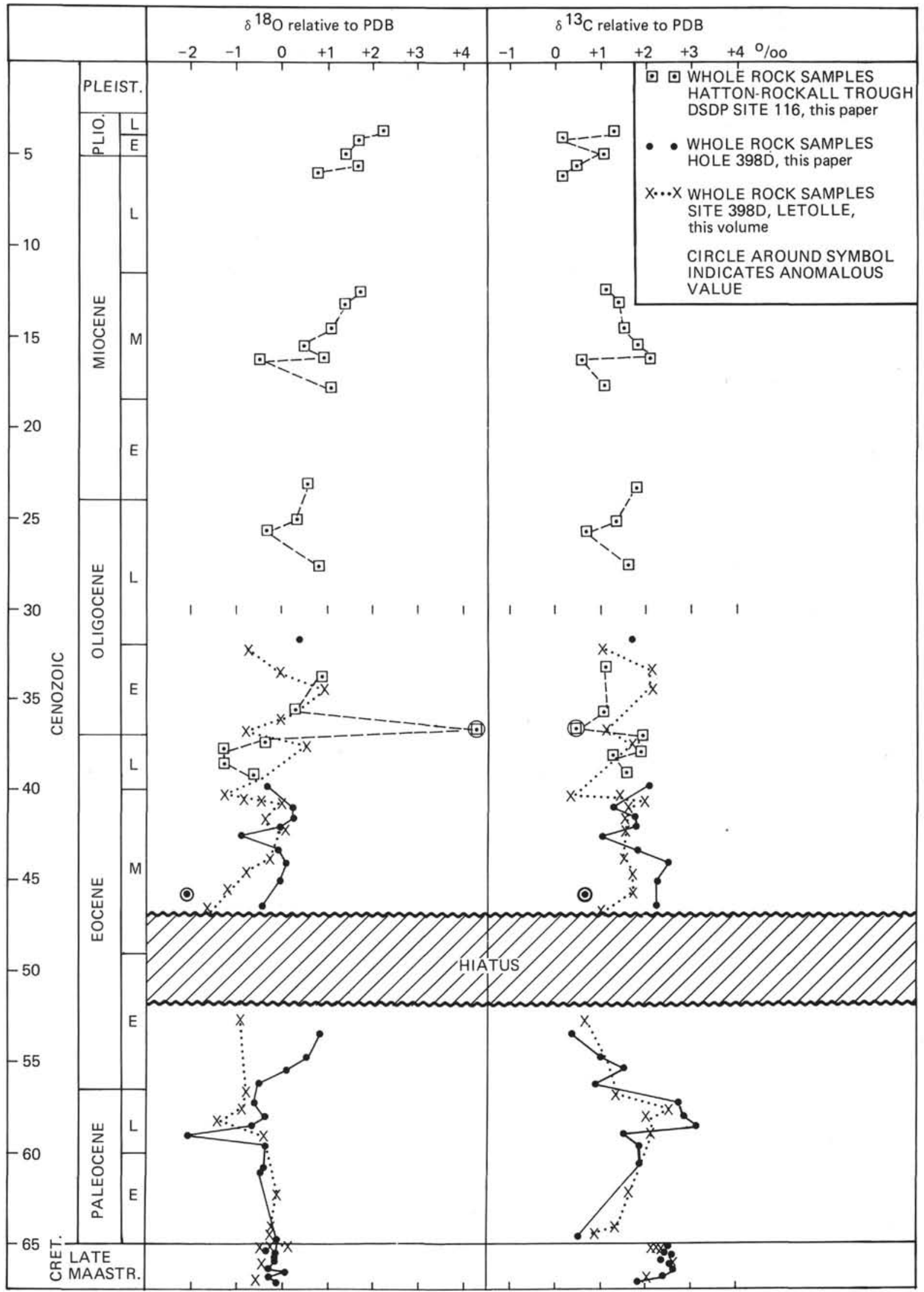

Figure 3. Cenozoic and late Maestrichtian whole rock stable isotope data for Sites 398 and 116, Eastern North Atlantic. Data include samples analyzed by Létolle (this volume) for comparison. 


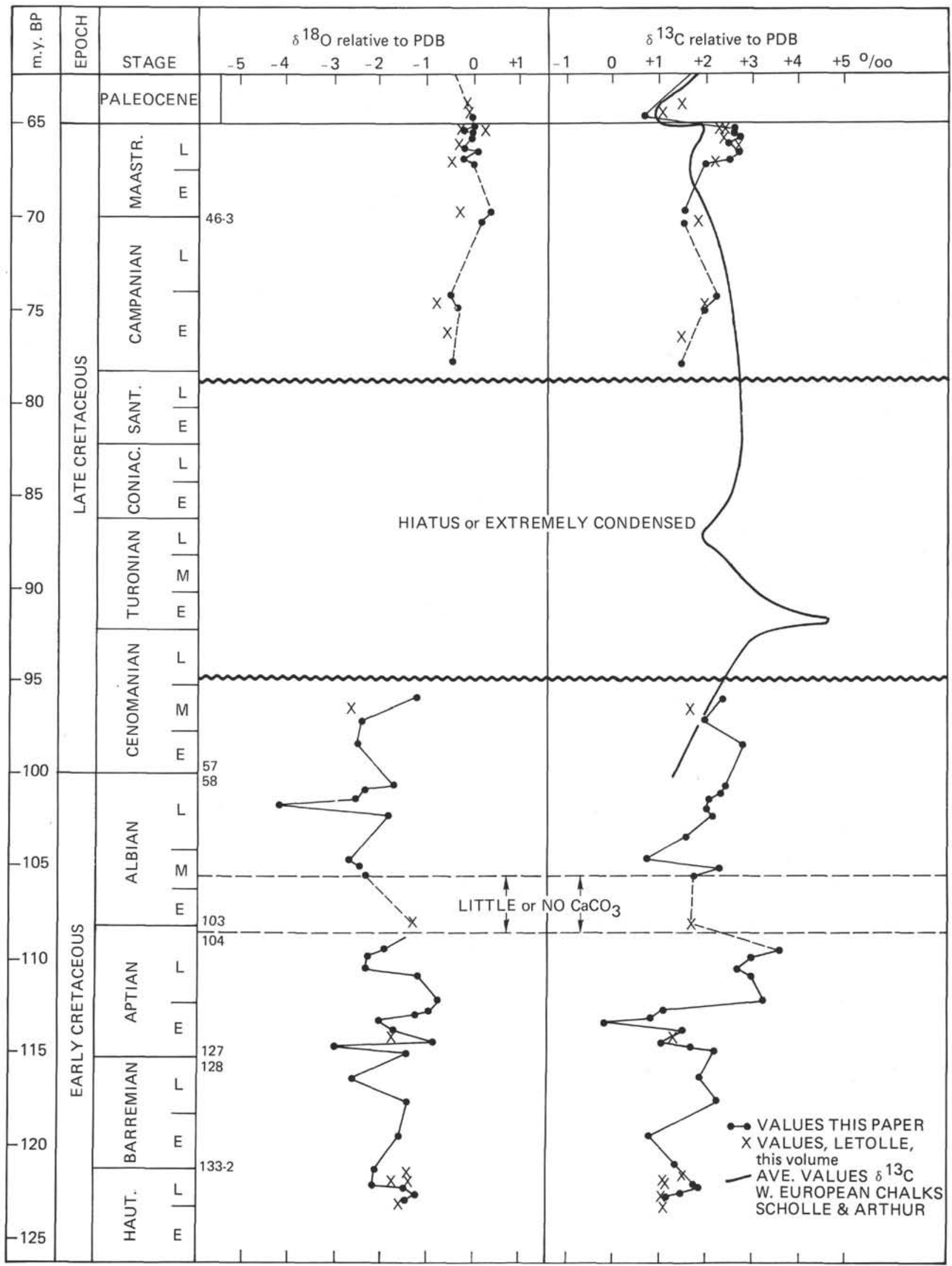

Figure 4. Cretaceous whole-rock stable isotopic data for this study, Hole 398D. Includes some samples analyzed by Létolle (this volume) as noted. 
of the variations in $\delta^{18} \mathrm{O}$ values are offered in the next section.

Carbon isotope values from the whole-rock samples of Sites 398 and 116 generally range between 0 and $+3 \%$ and show significant fluctuations with time, but no consistent trends with increasing depth of burial. In the record of Site 398 , heavy $\delta^{13} \mathrm{C}$ intervals (those values consistently greater than $+2 \%$ ) occur in sediments of middle Eocene, late Paleocene, late Maestrichtian, late Albian-middle Cenomanian, and late Aptian age. Lower $\delta^{13} \mathrm{C}$ values, approaching $1 \%$, are typical of intervals of early Eocene, earliest Paleocene, middle to late Albian, and early Aptian age, and are evident in the upper Miocene and Pliocene segments of Site 116. Fluctuations in the $\delta^{13} \mathrm{C}$ content of bulk carbonate from pelagic and hemipelagic sediment may be due to a number of complex factors such as (1) varying admixtures of calcareous constituents with different $\delta^{13} \mathrm{C}$ values (including redeposited shallow water material), (2) diagenetic overprints due to degradation of organic matter's methane formation and dissolution-reprecipitation reactions, and (3) variation in original $\mathrm{C}^{13}$ content with time due to carbon reservoir dynamics. These problems are treated briefly below.

\section{Analysis of Individual Foraminiferal Species}

Table 2 lists the species of planktonic and benthic foraminifers analyzed in this study, and their carbon and oxygen isotope compositions. The results for these foraminifers of Maestrichtian through Eocene age are plotted in Figure 5, using biostratigraphic age assignments from Iaccarino and Premoli Silva (this volume). Unfortunately, preservation was poor and numbers of individual planktonic foraminifers were low in the samples studied; consequently, a continuous sequence of planktonic foraminifers could not be obtained. A suspected hiatus during late early and early middle Eocene time (Iaccarino and Premoli Silva, this volume) also affects the continuity of the stable isotope results. Further complications causing problems in interpretation include significant reworking of foraminifers throughout this part of the section, some recrystallization and/or cement infilling of tests (even though samples were carefully selected to avoid this, if possible), and paucity and poor preservation of specimens from some very low $\mathrm{CaCO}_{3}$ intervals (Cores 51 to 47 , 38 , and 25 to 21 of Hole 398D). For each Cenozoic sample, we attempted to obtain analyses on at least one globigerinid and one globorotalid species when possible. Calcareous benthic foraminifers were present in almost every sample, although the genera in one sample were not always the same as those in the next. A fairly continuous sequence of calcareous benthics was analyzed.

Stable-isotope analyses of both planktonic and benthic foraminifers obtained here are not easily interpreted. Planktonic foraminifers show a wide range of oxygen and carbon isotope values, and no attempt has been made to pass curves through the values because of the lack of continuity of the sampling and the large isotopic differences between individual species and genera. Globigerinids are thought to inhabit more shallow surface waters than globorotalids and, therefore, should exhibit more negative values of $\delta^{18} \mathrm{O}$ (higher isotopic paleotemperatures) than either globorotalids or benthic foraminifers (Savin and Douglas, 1973); however, this is not always the case in our samples (398D-34-6 or 40-1). Late Maestrichtian globotruncanids consistently have more negative $\delta^{18} \mathrm{O}$ values than benthic foraminifers from the same samples. If interpreted in terms of isotopic paleotemperatures, the limited data from both planktonic and benthic foraminifers show warming during the late Maestrichtian to the Maestrichtian/Paleocene boundary, then a relative cooling of less than $4^{\circ} \mathrm{C}(\sim 0.7 \%)$ at this boundary with substantial fluctuations following in the Paleogene. Assemblages of calcareous nannoplankton in Site 398 also indicate a late Maestrichtian warming trend (Blechschmidt, pers. comm; see Site Report, this volume). The range of oxygen isotope values from individual foraminifers is generally more positive than that from whole-rock oxygen isotope numbers. This is predictable considering that calcareous nannofossils and some cement constitute the bulk of the sediment, and that these components usually have more negative initial $\delta^{18} \mathrm{O}$ values. A value of $+3.9 \%$ for a benthic foraminiferal assemblage in Section 398D-33-6 seems anomalously positive. Also puzzling are the large fluctuations in $\delta^{18} \mathrm{O}$ values of benthic assemblages, which are highly positive (relatively cooler paleotemperatures) in Campanian forms, and much more negative (relatively warmer) in late Maestrichtian assemblages. This excursion is not reflected in whole-rock values and may be a function of the preparation technique. More positive oxygen isotope values come from assemblages picked from $\mathrm{CaCO}_{3}$-poor red mudstones, while the more negative values are derived from relatively $\mathrm{CaCO}_{3}$-rich chalks. Possibly, the benthic foraminifers from the chalks contain more test-infilling cement of a ligher oxygen isotopic composition, or perhaps the thinnerwalled, warmer water tests are selectively dissolved. Values of $\delta^{18} \mathrm{O}$ obtained from benthic foraminifers are, in fact, relatively constant at about $+1 \%$ throughout the $\mathrm{CaCO}_{3}$-rich interval of Cores 398D-44 through 39, and fluctuate widely in more $\mathrm{CaCO}_{3}$-depleted intervals above and below. We observed sparry calcite infilling in some specimens from the $\mathrm{CaCO}_{3}$-rich interval, while those from the $\mathrm{CaCO}_{3}$-poor intervals had thin walls (possibly partly due to dissolution effects) and no visible cement infill. Benthic foraminifers are often recipients of later diagenetic calcite in chalks and limestones (Schlanger et al., 1973). We have not taken into account possible differences in isotopic fractionation between various genera or species of benthic foraminifers (Duplessy et al., 1970).

Carbon isotope values vary less than oxygen values through the section studied. Analyses of benthic foraminifers show relatively constant values through the Campanian to the Maestrichtian, becoming up to 0.8 or $1.0 \%$ heavier in the latest Maestrichtian and returning to lower $\delta^{13} \mathrm{C}$ numbers just above the Mae- 
TABLE 2

Stable Isotope Analyses of Individual Foraminifers, Hole 398D, Leg 47B

\begin{tabular}{|c|c|c|c|c|c|}
\hline $\begin{array}{c}\text { Sample } \\
\text { (Interval in } \mathrm{cm} \text { ) }\end{array}$ & $\begin{array}{l}\text { Planktonic or Benthic } \\
\text { Foraminiferal Species }\end{array}$ & Age & $\delta^{1}$ & $18_{0}$ & $\delta^{13} \mathrm{C}$ \\
\hline $19-4,78-79$ & Benthic, mostly nodisaria & Early middle Oligocene(?) & & 1.5 & -0.1 \\
\hline $19-4,78-79$ & Globigerina cf. G. oceanica & Early middle Oligocene(?) & & & \\
\hline $19-4,78-79$ & Nodisaria sp. & Early middle Oligocene(?) & & & \\
\hline $27-1$ & Planktic Globorotalia bulloides & Mid-middle Eocene & & -0.2 & 0.8 \\
\hline $27-1$ & Benthic assemblage & Mid-middle Eocene & & 0.4 & 1.9 \\
\hline $30-1,32-34$ & Benthic assemblage & Mid-middle Eocene & & -0.1 & 0.3 \\
\hline $33-6$ & Benthic assemblage & Early Eocene & & 3.9 & -0.2 \\
\hline $33-6$ & Globorotalia marginodentata & Early Eocene & & 1.5 & 1.5 \\
\hline $33-6$ & Globig. velascoensis & Early Eocene & & & \\
\hline $33-6$ & Globig. cf. triloculinoides & Early Eocene & & 1.2 & 0.7 \\
\hline- & Globorotalia cf. aequa & Early Eocene & & & \\
\hline $34-6$ & Benthic assemblage & Early Eocene & & 0.1 & -0.7 \\
\hline $34-6$ & Globigerina cf. G. triloculinoides & Early Eocene & $(2)^{\mathrm{a}}$ & 1.0 & 0.7 \\
\hline $34-6$ & Globorotalia marginodentata & Early Eocene & & 0.0 & 2.0 \\
\hline $36-1$ & Benthic assemblage & Late Paleocene & & 1.8 & 0.8 \\
\hline $36-5$ & Benthic assemblage & Late Paleocene & & 1.0 & 1.1 \\
\hline $38-3$ & Benthic assemblage & Late Paleocene & & & \\
\hline $38-3$ & Globorotalia trinidadensis & Late Paleocene & & & \\
\hline $38-3$ & Globorotalia pseudobulloides & Late Paleocene & & & \\
\hline $39-3,47-49$ & Benthic assemblage & Early Paleocene & & 1.9 & 0.6 \\
\hline $39-3,47-49$ & Globorotalia pseudobulloides & Early Paleocene & & 2.5 & 1.0 \\
\hline $39-3,47-49$ & Ammonia sp. Benthics & Early Paleocene & & 1.9 & 0.5 \\
\hline $39-3,47-49$ & Globorotalia cf. G. gracilis & Early Paleocene & $(2)^{\mathrm{a}}$ & 1.5 & 2.2 \\
\hline $39-4,87-89$ & Benthic assemblage & Early Paleocene & & 0.7 & 0.9 \\
\hline $39-4,87-89$ & Globorotalia cf. G. inconstans & Early Paleocene & & 1.1 & 2.4 \\
\hline $39-4,87-89$ & Globorotalia pseudobulloides & Early Paleocene & & & \\
\hline $39-4,87-89$ & Globorotalia uncinata & Early Paleocene & & & \\
\hline $39-4,87-89$ & Globorotalia triloculinoides & Early Paleocene & & 2.3 & 1.0 \\
\hline $40-1,109-111$ & Globig. fringa & Early Paleocene & & 1.8 & 1.6 \\
\hline $40-1,109-111$ & Benthic, Aragonia vulrulia & Early Paleocene & & 1.1 & 0.9 \\
\hline $40-1,109-111$ & Globig. daubjergensis & Early Paleocene & & & \\
\hline $40-1,109-111$ & Benthic assemblage & Early Paleocene & & 0.9 & 0.6 \\
\hline $40-1,109-111$ & Benthic Rotalia & Early Paleocene & & 1.1 & 0.7 \\
\hline $40-3,80-82$ & Benthic assemblage & Early Paleocene & & 0.9 & 0.6 \\
\hline $40-3,80-82$ & Globorotalia cf. G. pseudobulloides & Early Paleocene & & -0.4 & 0.8 \\
\hline $40-3,80-82$ & Globorotalia compressa & Early Paleocene & $(2)^{\mathrm{a}}$ & 1.9 & 1.1 \\
\hline $40-3,80-82$ & Globig. fringa & Early Paleocene & & & \\
\hline $40-3,80-82$ & Globig. eugubina & Early Paleocene & & & \\
\hline $41-1,9-11$ & Globorotalia pseudobulloides & Early Paleocene & $(2)^{\mathrm{a}}$ & 1.4 & 1.2 \\
\hline $41-1,9-11$ & Globig. fringa & Early Paleocene & & & \\
\hline $41-1,9-11$ & Globig. eugubina & Early Paleocene & & & \\
\hline $41-2,28-30$ & Osangularia sp. (benthic) & Early Paleocene & & 1.6 & 1.5 \\
\hline $41-2,28-30$ & Globigerina eugubina & Early Paleocene & & & \\
\hline $41-2,28-30$ & Benthic assemblage & Early Paleocene & & 1.2 & 0.7 \\
\hline $41-2,28-30$ & Reworked Planoglobulina & Early Paleocene & & & \\
\hline $41-2,28-30$ & Reworked Globotruncana rosetta & Early Paleocene & $(2)^{\mathrm{a}}$ & 0.1 & 1.6 \\
\hline $41-2,28-30$ & Reworked Racemiguembelina & Early Paleocene & & 0.9 & 2.0 \\
\hline $41-2,28-30$ & Reworked Pseudoguembelina sp. & Early Paleocene & & 0.4 & 2.0 \\
\hline $41-2,28-30$ & Reworked Pseudotextularia & Early Paleocene & & 1.1 & 1.9 \\
\hline $41-2,28-30$ & Woodringina hornerstownensis & Early Paleocene & & & \\
\hline $41-2,28-30$ & Ostracods & Early Paleocene & & 1.8 & 0.6 \\
\hline $41-2,45-47$ & Globotruncana cf. G. rosetta & Late Maestrichtian & $(2)^{\mathrm{a}}$ & 0.8 & 1.6 \\
\hline $41-2,45-47$ & Benthic Osangularia & Late Maestrichtian & & 0.4 & 1.0 \\
\hline $41-2,45-47$ & Benthic assemblage & Late Maestrichtian & & 0.5 & 1.4 \\
\hline $41-2,45-47$ & Globotruncana sp. & Late Maestrichtian & & 0.1 & $\begin{array}{l}1.4 \\
1.3\end{array}$ \\
\hline $41-2,51-53$ & Globotruncana cf. arca & Late Maestrichtian & $(2)^{a}$ & 0.3 & 1.4 \\
\hline $41-2,51-53$ & Globotruncana rosetta & Late Maestrichtian & & & \\
\hline $41-2,51-53$ & Osangularia sp. & Late Maestrichtian & & & \\
\hline $41-2,51-53$ & Benthic assemblage & Late Maestrichtian & & 0.7 & 1.5 \\
\hline $41-5$ & Benthic assemblage & Late Maestrichtian & & 0.8 & 0.7 \\
\hline $42-2$ & Benthic assemblage & Late Maestrichtian & & 1.1 & 1.0 \\
\hline $43-1$ & Benthic assemblage & Late Maestrichtian & & 1.1 & 1.7 \\
\hline $43-2$ & Benthic assemblage & Late Maestrichtian & & 1.1 & 1.4 \\
\hline $43-4$ & Benthic assemblage & Late Maestrichtian & & 1.4 & 1.1 \\
\hline $44-5,6-8$ & Mixed planktonic & Mid Maestrichtian & & 0.9 & 2.0 \\
\hline $44-5,6-8$ & Benthic assemblage & Mid Maestrichtian & & 1.0 & 1.3 \\
\hline $44-6,40-42$ & Benthics cf. Osangularia & Mid Maestrichtian & $(2)^{\mathrm{a}}$ & 1.1 & 1.2 \\
\hline $44-6,40-42$ & Benthic assemblage & Mid Maestrichtian & & 1.1 & 0.8 \\
\hline $45-4$ & Benthic assemblage & Early Maestrichtian & & & \\
\hline $46-1$ & Benthic assemblage & Late Campanian & & -0.1 & 0.4 \\
\hline $47-4$ & Benthic assemblage & Campanian & & 1.2 & 0.6 \\
\hline $48-2$ & Benthic assemblage & Campanian & & 2.8 & 0.8 \\
\hline $49-1,28-30$ & Mixed Verneuilina spp. & Campanian & & 1.5 & 0.8 \\
\hline $49-1,28-30$ & Osangularia sp. & Campanian & & 1.6 & 1.0 \\
\hline $49-1,28-30$ & Benthic assemblage & Campanian & & 1.2 & 0.9 \\
\hline $50-4,78-80$ & Benthic assemblage & Santonian(?) & & 2.2 & -0.5 \\
\hline
\end{tabular}

${ }^{\mathrm{a}}$ Denotes number of samples averaged to value. 


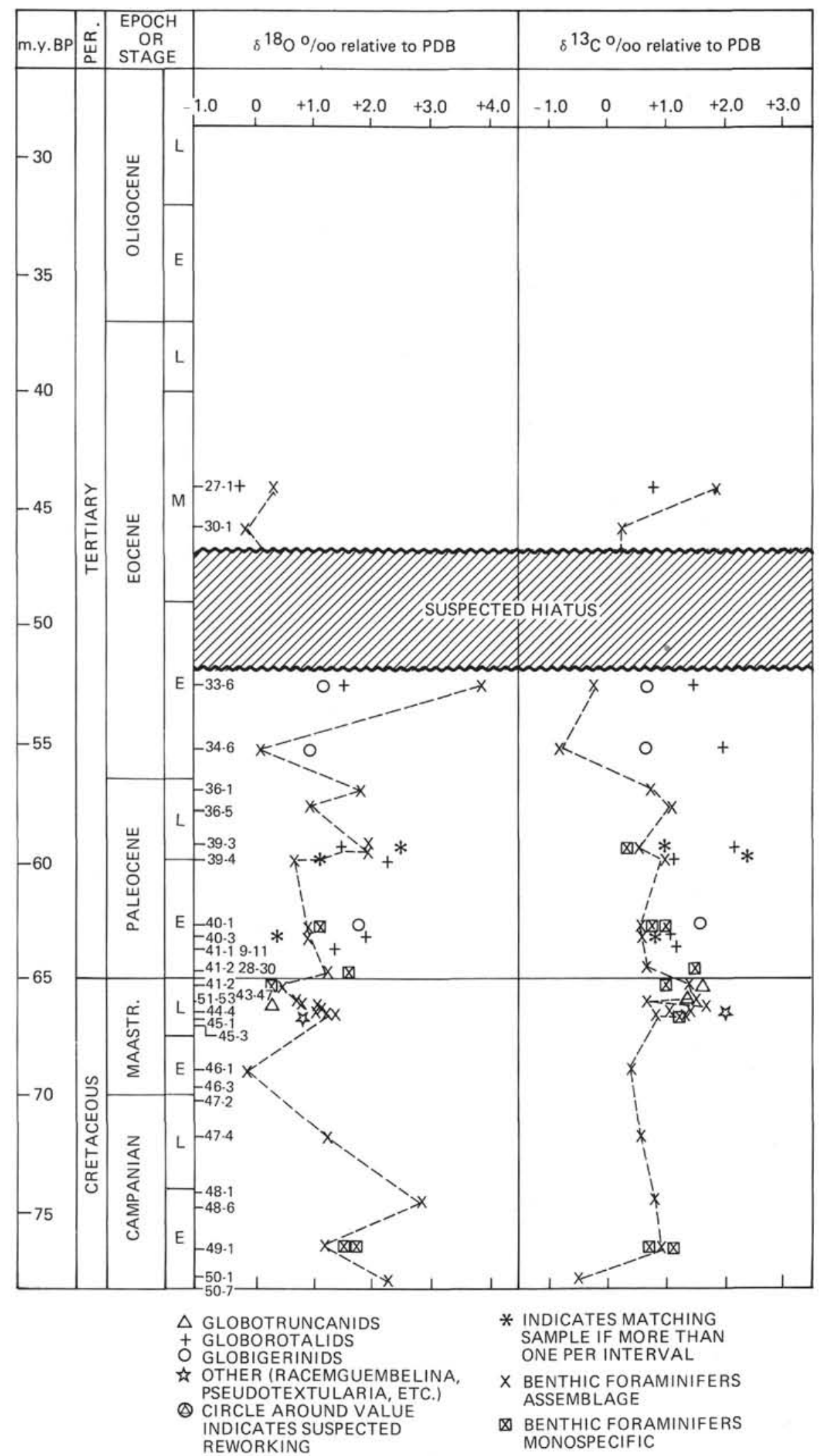

Figure 5. Stable isotope results from analysis of individual planktonic and benthic foraminifers, Hole 398D. 
strichtian Paleocene boundary. Values are less than $+1.0 \%$ oxcept for those few that represent the excursion to heavier values of $+1.5 \%$ in benthic assemblages of latest Maestrichtian age. This excursion is the same order of magnitude as that exhibited in bulk sediment analyzed from the same interval. Planktonic foraminifers show some carbon isotope variations through time; they usually exhibit more positive $\delta^{13} \mathrm{C}$ values than do benthic foraminifers at any one time. There is as much as 1.0 to $1.5 \%$ difference between individual globorotalid species or between globigerinids and globorotalids in any one sample, and as much as a $2.5 \%$ difference between planktonic and benthic foraminifers. These divergences of values are greater in early Eocene foraminifers than in those of any other portion of the stratigraphic record studied. For individual species of planktonic and benthic foraminifers, $\delta^{13} \mathrm{C}$ values cover the range of the bulk rock samples, but are generally $1.0 \%$ more negative than those in the whole-rock samples.

\section{DISCUSSION}

\section{Interpretation of Oxygen Isotope Data}

Interpretation of isotopic analyses of bulk samples involves a number of assumptions about the material being sampled. The $\delta^{18} \mathrm{O}$ values of lithified carbonate rocks certainly do not supply much information about the initial oxygen isotope composition of the sediment or paleotemperatures of surface or near-surface ocean waters. Much of the sedimentary material from the continental margin studied contains a record of the productivity of calcareous organisms in surface waters immediately above the site and those living at or below the sediment/water interface. The sedimentary material also presents a record of older reworked calcareous pelagic material and, in some cases, redeposited shallow-water material. All of these components have substantially different oxygen isotope compositions. Therefore, various admixtures can lead to variations in the bulk-rock isotopic composition. Progressive burial lithification, and dissolution and reprecipitation under increasing diagenetic temperatures, also leads to alteration of initial $\delta^{18} \mathrm{O}$ values.

With these factors in mind, we examined the bulkrock isotopic compositions downhole. In a wholly pelagic sedimentary section, variations in $\delta^{18} \mathrm{O}$ could be easily attributed to fluctuation of initial $\delta^{18} \mathrm{O}$ values due to temperature changes in surface waters with time or to the imprint of burial diagenesis. The lack of any consistent trends in oxygen isotope values from Site 398 , however, is most likely due to a combination of all the parameters outlined above. The Campanian through Eocene interval has a relatively uniform lithology; most of the lithologic differences are due to changes in carbonate content. Reworking of foraminifers occurs (Iaccarino and Premoli Silva, this volume), but the calcareous portion of the sediment is composed predominantly of nannofossils in varying states of preservation. Calcareous shallow-water material in samples analyzed from this interval is scarce.
Thus, it seems that some of the variation in $\delta^{18} \mathrm{O}$ values during Late Cretaceous to Paleogene time may be due to fluctuations in the initial oxygen isotopic composition of calcareous nannofossils resulting from surfacewater temperature variations at the site. Diagenetic modification due to reprecipitation is possible, but no significant progressive decreases in $\delta^{18} \mathrm{O}$ values can be noted in this depth interval from about 600 to 925 meters. Biogenic calcite in the entire interval may have been shifted to more negative values due to cementation; however, relative initial differences have probably been preserved. With this in mind, only a very slight cooling is recorded by bulk-rock $\delta^{18} \mathrm{O}$ analyses during Late Cretaceous time; no major Cretaceous/Tertiary boundary event is evident. Analyses from this boundary have been presented by previous workers (Douglas and Savin, 1973, 1975; Saito and van Donk, 1974); these data indicate cooling of surface waters in latest Maestrichtrian time. Data presented here may indicate an anomalous "warming" during late Maestrichtrian time. It has already been noted that oxygen isotope analyses of bulk samples of the more calcareous pelagic section at Site 116 may indicate relative paleotemperature variations from late Eocene through Pleistocene time with perhaps a negative oxygen isotope shift due to the overprint of progressive burial lithification with depth. The main oxygen isotopic shift at Site 398 may have occurred in the upper 400 to 500 meters and was not detected in this study because coring was discontinuous over that interval and therefore no samples were analyzed. The ooze-chalk transition occurs at about 320 meters (see Site Report) sub-bottom. Progressive lithification is evident.

Oxygen isotope values of both bulk rock samples and individual species of foraminifers seem to be much more variable in intervals of relatively low $\mathrm{CaCO}_{3}$ contents representing the period from Campanian through Eocene (Cores 398 D-38 to 34 , and 46 to 50 ). Samples from any part of the section containing less than about 15 to 25 per cent $\mathrm{CaCO}_{3}$ are unsuitable for whole-rock analyses because they give highly variable results. This variability is probably due to the low ratio of total initial carbonate in the sediment to the amount of carbonate dissolved in pore waters. Also the possibility of a biased, nonhomogeneous sample could affect the results. Dissolution effects increase the chances of sampling calcareous benthic foraminifers, which become predominant in the sediment as a refractory element. Thus oxygen isotope figures from bulk samples may be biased towards more positive $\delta^{18} \mathrm{O}$ values within intervals having low $\mathrm{CaCO}_{3}$ contents. Much of the sedimentary section from Site 398 was surprisingly poor in $\mathrm{CaCO}_{3}$. It may be difficult to obtain continuous and reliable bulk-rock stable isotope records from continental margin sites because of relatively high sedimentation rates and dilution of pelagic carbonate by terrigenous influx, as well as by contamination of redeposited shallow and deep water calcareous material.

Planktonic foraminifers of Cretaceous age are very poorly preserved and no attempt was made to analyze individuals. The portion of the sequence from mid-Ce- 
nomanian to late Hauterivian is relatively depleted of $\mathrm{CaCO}_{3}$ (Figure 2). A number of samples was analyzed from this interval, and they give variable results. Marly chalk samples of Cenomanian and latest Albian age are 1 to 2 per mil lighter in $\delta^{18} \mathrm{O}$ than marly chalks of Maestrichtian and early Paleocene age, which is predictable considering the deeper burial, further recrystallization, and probable lighter initial $\delta^{18} \mathrm{O}$ values of Albian-Cenomanian sediments. There is some possibility that the chalks in this interval are at least partially displaced from nearby topographic highs (Sigal, this volume; de Graciansky and Chenet, this volume). Isotopic values of samples of Albian through late Barremian age are extremely variable. Many anomalously positive $\delta^{18} \mathrm{O}$ values occur in samples of Albian and late Aptian age, coinciding with black to gray, organic carbon-rich, sideritic mudstones (Cores 398D-72 to 102) containing little or no original $\mathrm{CaCO}_{3}$. Samples rich in siderite have more positive $\delta^{18} \mathrm{O}$ and lighter $\delta^{13} \mathrm{C}$ values than those without. Because of the $\mathrm{CaCO}_{3}$ poor nature of this part of the section, only a few such samples were analyzed; no samples were examined in the interval from Cores 398D-76 to 104.

Analyses of samples from Cores 398D-105 to 138 (late Aptian to Hauterivian) give $\delta^{18} \mathrm{O}$ values generally lighter than $-1 \%$ o but are also variable. No attempt is made to interpret the values in this part of the section. Redeposited shallow-water carbonate or older nannofossil calcite may influence values in some of these samples (e.g., in Core 398D-105). The lowermost samples consist of recrystallized nannofossil limestone which has a relatively heavy oxygen isotope composition compared to what might be expected with burial to nearly 1800 meters sub-bottom depth. Most pelagic limestones buried to this depth under normal thermal gradients are shifted negatively several per mil (Scholle, 1974, 1977); values of $-3 \%$ are not common. It is puzzling that the Hauterivian nannofossil limestones of Hole 398D have average $\delta^{18} \mathrm{O}$ values not significantly different from nannofossil chalks much higher in the sequence, even though recrystallization is evident, porosity has been reduced, and strontium values are extremely low for a pelagic limestone (Renard and Létolle, this volume). Ryan, Sibuet, et al. (Site Report, this volume) have noted the anomalously low thermal gradient calculated from heat-flow data for this site. Bottom-hole temperatures may never have been sufficiently high to cause a great negative shift in the oxygen isotope composition of $\mathrm{CaCO}_{3}$. As noted before, no substantial $\delta^{18} \mathrm{O}$ gradient in calcite of bulk samples was evident from analyses in this study. The $\delta^{18} \mathrm{O}$ values from the Lower Cretaceous of Hole 398D are markedly more positive than those observed in Lower Cretaceous sediments from other North Atlantic sites (Scholle and Arthur, unpublished data; Brennecke, in press).

\section{Interpretation of Carbon Isotope Data}

The plot of carbon isotope data from bulk samples shown in Figures 3 and 4 illustrates a number of significant trends and fluctuations. Cenozoic $\delta^{13} \mathrm{C}$ values range between 0 and $+3 \%$ and no consistent rela- tionship between $\delta^{18} \mathrm{O}$ and $\delta^{13} \mathrm{C}$ is exhibited in individual samples. Anderson and Schneiderman (1973), among others, have previously demonstrated on anverse correlation between $\delta^{13} \mathrm{O}$ and $\delta^{18} \mathrm{C}$. However, the effect of temperatures on carbon isotopic fractionation in $\mathrm{CaCO}_{3}$ is relatively small (Emrich et al., 1970) and cannot account for the range of values found within the samples analyzed here. There is a coincidence of heavier $\delta^{13} \mathrm{C}$ values with higher oceanic paleotemperatures, at least in the Cenozoic (Fischer and $\mathrm{Ar}$ thur, 1977): this generally holds true for Sites 398 and 116 as well. In pelagic limestones, changes through time in $\delta^{13} \mathrm{C}$ values probably reflect variations in the overall $\delta^{13} \mathrm{C}$ composition of the surface-water carbon reservoir. These variations are due to local conditions of productivity (upwelling) and to changes with time in the carbon fractionation ratio between the organic matter and the carbonate reservoirs. Periods of unusually high rates of deposition and preservation of organic carbon in marine sediments, such as those which occurred during early and middle Cretaceous time, may result in much heavier $\delta^{13} \mathrm{C}$ values (more positive) in the ocean reservoir and, consequently, in biogenic calcite (Fischer and Arthur, 1977; Scholle and Arthur, 1976). The abrupt positive $\delta^{13} \mathrm{C}$ peak in the upper Paleocene data (Figure 3: a rapid change over 1 per mil) has also been recognized in pelagic carbonates from the Pacific Ocean (Douglas and Savin, 1975). At Hole 398D, it is exhibited more clearly in whole-rock samples than in individual foraminifers.

Another interesting carbon isotope event occurs at the Cretaceous Tertiary boundary. $\delta^{13} \mathrm{C}$ values hover near $+1.5 \%$ during the Campanian to mid-Maestrichtian interval, and increase to $+2.5 \%$ during late Maestrichtian time. A sudden decrease of up to 1 to 2 $\%$ occurs at the boundary. We have observed this same relationship in some sections of pelagic sediments from Europe (see curve, Figure 4, for comparison); this decrease may be due to a substantial drop in productivity near the boundary or to a change in the carbon-isotope composition of surface waters at this time due, perhaps, to increased upwelling or intermediate waters. Values increase again fairly rapidly in the Paleocene, perhaps indicating readjustment of pelagic communities or cessation of the peculiar oceanic conditions over the site.

Unfortunately, no isotopic record is available from North Atlantic DSDP sites for the mid-Cenomanian to Santonian interval. Values from sediments of Early Cretaceous age again show pronounced fluctuations, especially within the interval of dark, organic-rich mudstones having low $\mathrm{CaCO}_{3}$ content, some with substantial amounts of siderite. Values of $+3 \%$ occur in strata of late Aptian age, but the expected trend to high positive values in the organic carbon-rich shale of Early Cretaceous age (late Barremian to middle Albian) is not apparent in this section. This is probably due to diagenetic effects within the generally low- $\mathrm{CaCO}_{3}$ Cretaceous section. Most of the $\delta^{13} \mathrm{C}$ values lighter than $+1 \%$ occur within the organic-rich, siderite-rich section. Siderite and calcite of diagenetic origin probably have light carbon isotope compositions (Sections 
$398-63-5 ; 67-1 ; 72-3)$ because much of the diagenetic carbonate carbon may have been derived from oxidation of isotopically light organic carbon. The overall carbonate carbon reservoir in the sediment was probably small relative to the pore-water carbon and organic carbon reservoirs. The $\delta^{13} \mathrm{C}$ values are more constant and the trends are more consistent within intervals of higher $\mathrm{CaCO}_{3}$ contents $(>25 \%)$ throughout Site 398; therefore, we believe that these data are more dependable.

\section{CONCLUSIONS}

$\mathrm{CaCO}_{3}$ from bulk samples of most lithologies from Sites 398 and 116 was analyzed for carbon and oxygen isotope composition. Samples having $<25$ per cent $\mathrm{CaCO}_{3}$ were generally unsuitable for interpretation of primary isotope composition and gave variable and often anomalous results. This may be a typical problem in continental margin sites.

No continuous trends toward progressively negative $\delta^{18} \mathrm{O}$ values downhole we found at Site 398 . In fact, $\delta^{18} \mathrm{O}$ values of recrystallized nannofossil limestones are more positive than expected for the depth of burial at Site 398. Some fluctuation in $\delta^{18} \mathrm{O}$ of bulk samples can be attributed to variation in original isotopic composition due to paleotemperature variations. Carbon isotope values show more consistent trends and, except for a number of values in the Lower Cretaceous section that are isotopically light due to diagenetic effects, may reflect original variations in the carbon isotope composition of the ocean reservoir. Significant isotopic fluctuations occur near the Cretaceous/Tertiary boundary and in the upper Paleocene section.

More analyses of individual planktic and benthic foraminifers are needed before paleotemperature trends and relations among species can be documented for the interval from Maestrichtian through Eocene time in the North Atlantic. The data obtained in this study show inconsistent relationships in $\delta^{18} \mathrm{O}$ between species of planktonic foraminifers and between planktonic and benthic foraminifers. Differences in $\delta^{13} \mathrm{C}$ values from each group seem more constant. Only a slight cooling at the Cretaceous/Tertiary boundary is evidenced by benthic and planktonic foraminifers.

\section{ACKNOWLEDGMENTS}

We would like to thank Stan Margolis and Peter Kroopnick at the Hawaii Institute of Geophysics, and Bob Matthews and Bob Fifer of Brown University (Benedum Stable Isotope Lab) for careful analyses of the oxygen and carbon isotope compositions of many of the samples reported here. We are also indebted to them for attentive reviews and suggestions for improving the manuscript. They do not agree with all of our interpretations, of course, and any errors remain our responsibility. The National Science Foundation (NSF Grant DES 74-22214) supported one of us (MAA) during a portion of this project.

\section{REFERENCES}

Anderson, T. F. and Schneidermann, N., 1973. Stable isotope relationships in pelagic limestones from the central Caribbean. In Edgar, N. R., Saunders, J. B., et al., Initial
Reports of the Deep Sea Drilling Project, v. 15: Washington (U.S. Government Printing Office), p. 795-803.

Berggren, W. A., 1972. A Cenozoic time scale - some implications for regional geology and paleobiogeography, Lethaia, v. 5, p. 195-215.

Brenneke, J. C., 1978. A comparison of the stable oxygen and carbon isotopic composition of early Cretaceous and Late Jurassic carbonates from Sites 105 and 367, DSDP. In Lancelot, Y., Seibold, E., et al., Initial Reports of the Deep Sea Drilling Project, v. 41: Washington (U.S. Government Printing Office), p. 937-956.

Coplen, T. B. and Schlanger, S. O., 1973. Oxygen and carbon isotope studies of carbonate sediments from Site 168, Magellan Rise, Leg 17. In Winterer, E. L., Ewing, J. I., et al., Initial Reports of the Deep Sea Drilling Project, v. 17: Washington (U.S. Government Printing Office), p. 505509.

Craig, H., 1957. Isotopic standards for carbon and oxygen and correction factors for mass-spectrometric analysis of carbon dioxide, Geochim. Cosmochim. Acta, v. 11, p. 133.

Craig, H., 1965. The measurement of oxygen isotopic paleotemperatures, Spoleta Conf. Stable Isotopes Oceanogra. Stud. Paleotemp. Proc., v. 3, p. 1.

Douglas, R. G. and Savin, S. M., 1971. Isotopic analysis of planktonic foraminifera from the Cenozoic of the N. W. Pacific, Leg 6. In Fischer, A. G., Heezen, B. C., et al. Initial Reports of the Deep Sea Drilling Project, v. 6: Washington (U.S. Government Printing Office), p. 1123-1127.

1973. Oxygen and carbon isotope analyses of Cretaceous and Tertiary foraminifera from the central North Pacific. In Winterer, E. L., Ewing, J. I., et al., Initial Reports of the Deep Sea Drilling Project, v. 17: Washington (U.S. Government Printing Office), p. 591-605.

1975. Oxygen and carbon isotope analyses of Tertiary and Cretaceous microfossils from Shatsky Rise and other sites in the North Pacific Ocean. In Larson, R. L., Moberly, R., et al., Initial Reports of the Deep Sea Drilling Project, v. 32: Washington (U.S. Government Printing Office), p. 509-521.

Duplessy, J. C., Lalou, C., and Vinot, A. C., 1970. Differential isotopic fractionation in benthic foraminifera and paleotemperatures reassessed, Science, v. 168, p. 250-251.

Emrich, K., Ehart, E. H., and Vogel, J. C., 1970. Carbon isotope fractionation during the precipitation of calcium carbonate, Earth Planet. Sci. Letl., v. 8, p. 363-371.

Fischer, A. G. and Arthur, M. A., 1977. Secular variations in the pelagic realm. In Cook, H. E. and Enos, P. (Eds.), Soc. Econ. Paleontoe. and Mineralogists Spec. Publ. No. 25, Basinal carbonate sediment, p. 19-50.

Haq, B. U., Premoli-Silva, 1., and Lohmann, G. P., 1977. Calcareous plankton paleobiogeographic evidence for major climatic fluctuations in the early Cenozoic Atlantic Ocean, J. Geophys. Res., v. 82, p. 3861-3876.

Lloyd, R. M. and Hsü, K. J., 1972. Stable isotope investigations of sediments from the DSDP III cruises to South Atlantic, Sedimentology, v. 19, p. 45.

Margolis, S. V., Kroopnick, P. M., Goodney, D. E., Dudley, W. C., and Mahoney, M. E., 1975. Oxygen and carbon isotopes from calcareous nannofossils as paleo-oceanographic indicators, Science, v. 189, p. 555-558.

Matter, A., Douglas, R. G., and Perch-Nielsen, K., 1975. Fossil preservation, geochemistry, and diagenesis of pelagic carbonates from Shatsky Rise, Northwest Pacific. In Larson, R. L., Moberly, R., et al., Initial Reports of the Deep Sea Drilling Project, v. 32: Washington (U.S. Government Printing Office), p. 891-922. 
Saito, T. and van Donk, J., 1974. Oxygen and carbon isotope measurements of Cretaceous and early tertiary foraminifera, Micropaleontology, v. 20, p. 152-177.

Savin, S. M. and Douglas, R. G., 1973. Stable isotope and magnesium geochemistry of Recent planktonic foraminifera from the South Pacific, Geol. Soc. Am. Bull., v. 84, p. 2327-2342.

Savin, S. M., Douglas, R. G., and Stehli, F. G., 1975. Tertiary marine paleotemperatures, Geol. Soc. Am. Bull., v. 86, 1499-1510.

Schlanger, S. O. and Douglas, R. G., 1974. The pelagic oozechalk-limestone transition and its implications for marine stratigraphy. In Hsü, K. J. and Jenkyns, H. C. (Eds.), Pelagic sediments: on land and under the sea, Spec. Publ. Int. Assoc. Sediment., v. 1, p. 117-148.

Schlanger, S. O., Douglas, R. G., Lancelot, Y., Moore, T. C., Jr., and Roth, P. H., 1973. Fossil preservation and diagenesis of pelagic carbonates from the Magellan Rise, central North Pacific Ocean. In Winterer, E. L., Ewing, J. I., et al., Initial Reports of the Deep Sea Drilling Project, v. 17. Washington (U.S. Government Printing Office), p. $407-$ 427.
Scholle, P. A., 1974. Diagenesis of Upper Cretaceous chalks from, England, Northern Ireland, and the North Sea. In Hsü, K. J. and Jenkyns, H. C. (Eds.), Pelagic sediments on land and under the sea, Spec. Publ. Int. Assoc. Sediment., v. 1 , p. $177-210$.

, 1977. Chalk diagenesis and its relation to petroleum exploration: oil from chalks, a modern miracle?, AAPG Bull., v. 61, p. 982-1009.

Scholle, P. A. and Arthur, M. A., 1976. Carbon-isotopic fluctuations in upper Cretaceous sediments: an indicator of paleo-oceanic circulation, Geol. Soc. Amer. Abstr. with Prog., v. 8, p. 1089.

Shackleton, N. J. and Kennett, J. P., 1975. Paleotemperature history of the Cenozoic and the initiation of Antarctic glaciation: Oxygen and carbon isotope analyses in DSDP Sites 277, 279, and 281. In Kennett, J. P., Houtz, R. E., et al., Initial Reports of the Deep Sea Drilling Project, v. 29: Washington (U.S. Government Printing Office), p. 743-755.

Van Hinte, J. E., 1976. A Cretaceous time scale, Am. Assoc. Petrol. Geol. Bull., v. 60 , p. $498-516$. 